\title{
The Influence of Soft Skills and Hard Skills on the Competence of Vocational High School Graduate Students in the Field of Building Construction
}

\author{
Soeparno, Department of Civil Engineering Education, Faculty of Engineering, Universitas Negeri Surabaya, \\ Indonesia,soeparno@unesa.ac.id \\ Luthfiyah Nurlaela, Department of Economics Education, Faculty of Engineering Universitas Negeri \\ Surabaya Indonesia, luthiyahnurlaela@unesa.ac.id \\ Eko Hariadi, Department of Information Engineering Education, Faculty of Engineering, Universitas Negeri \\ Surabaya Indonesia, ekohariadi@unesa.ac.id \\ Supari, Department of Electronics Engineering Education, Faculty of Engineering, Universitas Negeri \\ Surabaya Indonesia, supari@unesa.ac.id \\ Suparji, Department of Building Engineering Education, Faculty of Engineering, Universitas Negeri Surbaya \\ Indonesia, suparji@unesa.ac.id
}

Agus Wiyono, Department of Civil Engineering Education, Faculty of Engineering Universitas Negeri Surbaya Indonesia, aguswiyono@unesa.ac.id

\begin{abstract}
The Indonesian Central Bureau of Statistics (BPS) released the unemployment rates in Indonesia in February 2020. The highest open unemployment rate (TPT) occurred in residents with Vocational High School (SMK) graduates, reaching $8.63 \%$, followed by Diploma I/II/III and high school (SMA) levels, respectively $6.89 \%$ and $6.78 \%$. This becomes very ironic because the aim of SMK is to produce competent graduates who are ready to work in the industrial world (DUDI). Therefore, SMK graduates are expected to have the competencies needed by DUDI. The purpose of this study was to determine soft skills competencies, and hard skills competencies required by the industry. This type of research is qualitative and the data collection technique is carried out by using questionnaires and focus group discussions with DUDI parties. Data analysis uses Affinity diagrams (K-J method), which makes it easier to analyze data from brainstorming. The results of this study can identify soft skill competencies: honest, thorough, able to solve, adaptable, able to work as a team, able to work under pressure while hard skill competencies: survey, mapping, drawing, structure and construction cost estimation, and project scheduling.
\end{abstract}

Keywords: Influence, soft skills, hard skills.

Received: 09.12.2020 $\quad$ Accepted: 17.01.2021 $\quad$ Published: 06.02.2021

\section{INTRODUCTION}

The Indonesian Central Bureau of Statistics (BPS), in February 2020 released the statement regarding the unemployment in Indonesia. From the statement release, it shows that the open unemployment rate (TPT) highly occurs among vocational high school graduates (SMK) by 8,63\%, followed by I/II/III Diplomas and Senior High School graduates which each of them rate within 6,89\% and 6,78\%. Ironically, this happens in oppose to the purpose of vocational high school which is to produce the competent graduates who are capable in working industry (DUDI). Therefore, vocational high school graduates are expected to have the competence that is needed by DUDI.

The competence of vocational high school graduates have to be suitable with the requirements that are needed by DUDI, followed by the development of science and technology. The fact in real situation shows that many of the vocational high school graduates in Building Construction major do not have the suitable competence with what the building construction industry needs.

1.1. Vocational High School (SMK)

Secondary education is education at the secondary level that prioritizes the development of students' abilities for certain types of work. Vocational secondary education has to be able to produce the graduates who are independent in the certain type of work. The graduates are expected to not only search for job, but also create job opportunities by themselves. The function of vocational education is to equip the students with sciences and technology, and also the wellness of professions which suitable in the society and to develop the physical and mental wellness to live independently in the society and or to 
continue higher education. Vocational secondary school is the key in the economic growth that are able to equip the students with the vocational capability to develop the expertise and to decrease the number of poverty (Bagale, 2015). Vocational secondary school is the main medium of human resources (Chinedu, Wan-Mohamed, \& Ajah, 2018).

The main purpose of vocational secondary education is to produce the graduates who are ready in working fields. It provides the specific productive training with the guide from the teachers to develop the expertise in the certain type of industries. Vocational education provides the motivation to the students to increase their expertise in order to be able to work after they graduate and to able to economically provide outcomes (Pavlova, 2009). The purpose of vocational education is to identify the types of job opportunities that are suitable for their own ability and to contribute to effectively develop the work capacity (Billets, 2011).

Based on the above study, Vocational secondary school (SMK) is the secondary education which has the purpose to equip the students with expertise in the certain type of work. Vocational school graduates have the expertise which can be used in the working field. Therefore, SMK graduates will not have any difficulty to search for work.

\section{Competency}

Year by year information and technology keep developing which make the work industry is also developing the individual expertise needed and the tools and equipments which are getting more advanced. Rapid change is a part that has to be faced by each individual. Those changes imply directly to the need of competence. Definition and Selection of Competencies (DeSeCo, 2005) explains the competency is more than only about science and expertise. Competency covers the ability to fulfill the complex request by using and mobilizing the psychological resources as well as the expertise and attitude in the suitable context. Competency in a certain work field needs to be mapped in order to make it easier for continuous competency development, because competency will develop along the way as well as the development of technology and era (Francesco Melosi, Campana. G, Cimatti. B. 2018).

Knowledge, expertise and attitude are the necessary components in the development of career which becomes the main competency of the vocational high school graduates. There are six competency frameworks which are: strategic management competence and action competence, embracing diversity and interdisciplinary competence, systems thinking competence, normative competence, and Interpersonal competence (Ploum et al, 2017).

The important outcomes for vocational education are giving the expertise to the students with theoretical knowledge and professional expertise, and developing the ability of the students with the continuous competency (Zhang, J. \& Zhang, Y, 2012). The competence of the graduates is influenced by the educators-professional educators who have the competence that can transfer the knowledge and expertise of the students. The teachers who are able to teach the expertise and teach them with the suitable productive teaching method will be able to produce well-competent graduates (Liu, $\mathrm{H}$., Hartmann, M., Liu, M, \& Hariyanto, D, 2019). A competent and professional teacher in the system of well productive learning will be able to support the achievement of vocational high school graduates' competence (Estriyanto. Y, Kersten. S, Pardjono, Sofyan. H. 2017).

Based on the explanation above, it can be concluded that competency is the expertise (cognitive, affective, and psychomotor) which possessed by the students after they graduate from the vocational high school. Competency, as the outcome of the learning, can be in the form of soft skill and hard skill. It has to be suitable with the needs of the industry world. Competency has to be developed alongside the development of technology.

\section{Construction Industry}

Constitution Number 22017 about construction service explains that construction service is construction consulting service and or construction work. Construction consultation is the service as a whole or a part of the activities such as: study, plan, design, supervise, and manage the construction of a building. Construction work is a whole or part of the activities which consists of: construction, operation, maintenance, demolition, and reconstruction of a building.

The purpose of providing construction service based on the constitution article 3 Number 22017 which states as follows: (1) provide a direction for the growth and development of Construction Services to create a business structure that is strong, reliable, highly competitive, and good quality Construction Services, (2) realizing orderliness in the operation of Construction Services which guarantees equal position between Service Users and Service Providers in exercising their rights and obligations, and enhancing compliance in accordance with the provisions of laws and regulations, (3) realizing increased public participation in the field of Construction Services, (4) arranging a construction service system that 
capable of realizing public safety and creating a comfortable built environment, (5) guaranteeing a good governance in the operation of Construction Services, (6) creating integration of added value from all stages of Construction Service operation.

Government Regulation Number 29 of 2000 concerning the Implementation of Construction Services explains that service providers consist of construction planners, construction executors, and construction supervisors. Construction planners, according to Regulation of the Minister of Public Works Number 08/ PRT/M/2011 are service providers for individuals or business entities that are declared as professional experts in the field of construction service planning who are capable of realizing work in the form of planning documents or other physical forms. A construction implementer is a service provider by an individual or a business entity declared as a professional expert in the field of construction service implementation capable of carrying out activities to turn a planning result into a building or other physical form. Construction supervisors are service providers who are individuals or business entities declared as professional experts in the field of construction service supervision who are capable of carrying out construction supervision work until it is completed and handed over.

Article 5 of the Regulation of the Minister of Public Works Number 08 / PRT / M / 2011 describes the classification of construction services which includes (1) classification of construction planning and supervision services (architecture, engineering, spatial planning; and other consulting services), (2) classification of fields construction implementation service businesses (buildings, civil buildings, mechanical and electrical installations, and other implementation services. Article 17 of the Minister of Public Works Regulation Number 08/PRT/M/2011 describes the qualifications of construction service business entities which include large business qualifications, medium business qualifications, and small business qualifications.

A project is an activity that is only carried out once and generally takes place in a short period of time or, in other words, a project activity can be interpreted as a temporary activity that lasts for a limited period of time, with the allocation of certain resources. Whilst, building construction is the construction of a building. Therefore, a construction project is an attempt to construct a building for a certain time while using limited project resources.

The quality of the students' competence can be increased through curriculum by including three parties which are the people of the school, government and company. The competence of the vocational high school students can be in the form of soft skill and hard skill expertise. The form of students' competence that being taught in the school has to be suitable with society needs. The thing being used as the foundation of education to produce the suitable competence of the students with the purposes is curriculum. The students' mindset on when they get graduated and get the job afterwards with whatever job opportunities available (including the jobs that are not correlated with their expertise or competency) causes the career path and the work period of the vocational school graduates tend to be low. Therefore, the students need to be given the understanding on the importance of education and training after they are graduated from school, because these educational investments can increase the bargaining value and the ability of students to prepare them to enter the working world. One of the forms of formal educational investments can be implemented by optimizing the career plan at school. Career plan program in vocational school is needed in order to lead the students to be able to determine their interest and ability that they have that are suitable in the working world.

The people have to be involved in the determination of vocational school curriculum in order to make the competency of the graduates can be suitable for the society's needs. The involvement of the people in vocational high school is to be the members of school committee. School Committee is the crucial institution for the continuity of the school. Khan et. al (2013: 3) explains that school committee has the responsibility in several aspects such as: administrative, academic, and school financial. School committee must rely on the foundation of community participation in improving the quality of services and educational outcomes in schools.

Dmitry \& Elena (2015) added that there is a lack of communication with the organization or industry that uses graduates, therefore, the competence of graduates with the needs of the job market do not match. The curriculum arrangement that does not pay attention to the needs of the users will cause the lack of graduates being hired in the industry. M Kuijper et. al (2011) explains that career guidance in the school gives a huge contribution towards the suitability between the competency of the graduates and the competency needed in the industry. With no communication between the school and DUDI, there will not be any suitability of competencies. The competency of vocational school graduates can adjust to the needs of DUDI if there is any connection and communication between them. Communication can be done by involving DUDI as the member of the school committee. DUDI can be invited to arrange the curriculum and competency needed in order to be relevant. 
Based on the explanation above, the study of Building Engineering vocational high school's competency needed by the construction industries are necessary to be implemented. The purpose of the study is to find out the soft skill and hard skill competency needed by the construction industry.

\section{METHODOLOGY}

This research uses qualitative method. The subjects for this study are construction industries and vocational high school in building engineering. The location of the research is Surabaya. The subjects are five vocational high school and DU/DI in building engineering. Vocational high schools of building engineering that are used as the subject are SMK Negeri 2 Surabaya, SMK Negeri 3 Surabaya, SMK Negeri 5 Surabaya, and SMK Negeri 7 Surabaya. DUDI in construction field are: PT. Tatalaksana Konstruksi, PT. Tatamatra Indonesia, PT. Delta Buana, PT. Duta Rama, and PT. Ris Putra Delta. The data collection technique is by distributing questionnaire and focus group discussion. The analysis technique used is Affinity diagram (K-J Method), which is the easy way to analyse the brainstorming data.

\section{RESULTS AND DISCUSSION}

\section{Soft skill Competency}

Data collection towards DUDI is done by using questionnaires which contain suitable of competencies with the curriculum of Vocational high school in building engineering. Competencies that are mentioned in the questionnaires consist of: attitude competency, knowledge, and skills. Other than the alreadyincluded competencies in the curriculum, it is also provided the additional space to be filled with the competency needed by DU/DI by which it has/have not been included in Vocational high school of Building Engineering curriculum.

Based on the questionnaires of attitude, the highest score is owned by first number 1 competency, followed by 4 and 9 which are: being honest at work, paying attention to detail, and problem solving. For further results of attitude, they can be seen in the graphic (Figure 1) below.

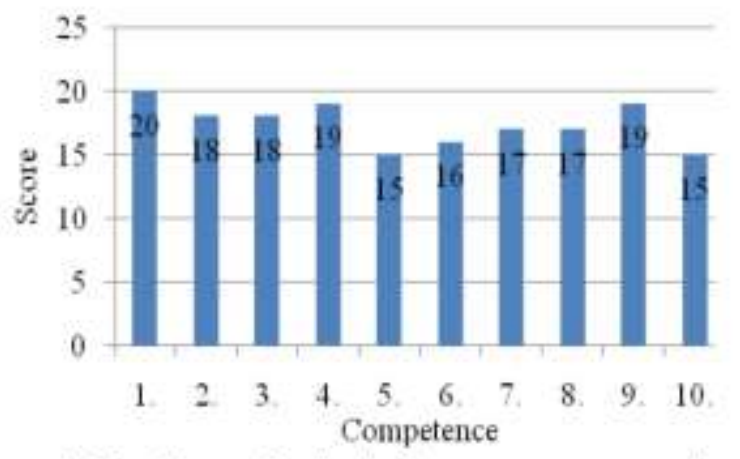

Figure 1. Graphic result of attitude competency questionnaires

The additional competency suggested by DU/DI parties in attitude competency is easily adapting, able to work in a team, able to work under pressure, amble to understand the necessity in the fields, and never give up. Attitude competencies or soft skills that have to be led to the needed competencies in the industries in industrial revolution era 4.0 are critical thinking and problem solving. This is based on the Definition and Selection of Competencies (DeSeCo, 2005) which explains the competencies cover the ability to fulfill the complex needs by using and mobilize the psychological resources such as the skill and attitude in the appropriate context.

\section{Hard Skill Competency}

Based on the questionnaires of knowledge competency or cognitive, it can be seen that the highest competency is number 6 , followed by 4 and 7 which are understanding the components of the buildings, understanding the building materials, and understanding how to use the software to design/draw (CAD). For the detail results, it can be seen from the graphic (Figure 2) below. 


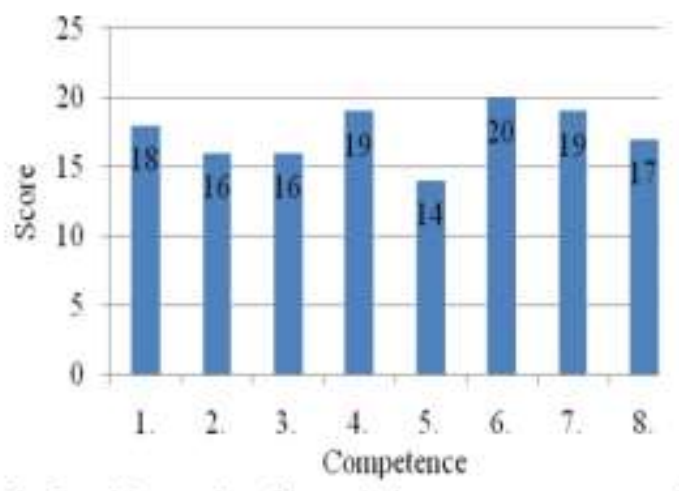

Figure 2. Graphic results of knowledge competency questionnaires

Additional competencies suggested by DU/DI in knowledge competence are understanding the building work process, being able to describe technical drawing problems so that it is easy for everyone to understand, understanding building electrical installation drawings, and understanding building water installation drawings.

Based on the skill or psychomotor competency questionnaire, it can be seen that the highest score is competency number 7, followed by 6 and 3, namely implementing occupational safety and health (K3) procedures, applying building materials according to building needs, and being able to use software for engineer drawing (AutoCAD). For more details, the results of the knowledge questionnaire can be seen in Figure 3.

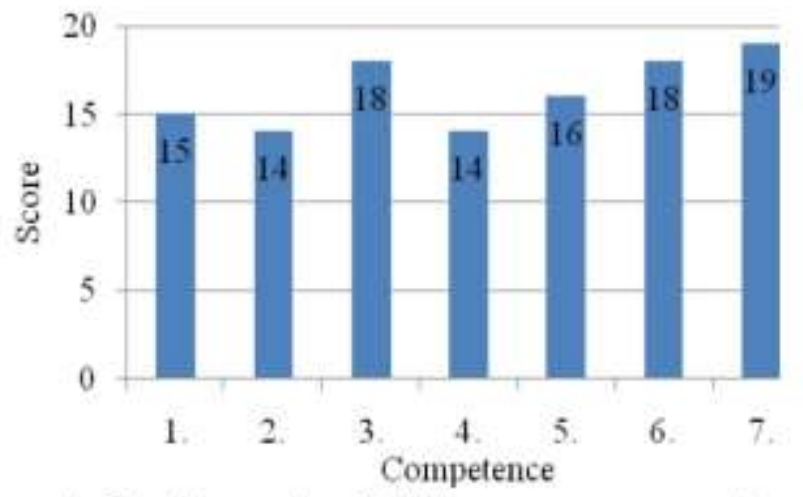

Figure 3. Graphic results of skills competency questionnaires

Additional competencies suggested by the DU/DI in skills competencies are as follows: being able to present attractive shop drawings, being able to adjust the scale and font of the letters in the image to make them suitable and attractive, to adjust the thickness and thinness of the lines on the AutoCAD layer to make it more attractive, to draw architectural details , drawing structural details, drawing steel construction buildings, drawing details of steel construction joints, drawing the situation along with GSJ and GSB for IMB, drawing complete shop drawings (floor plans, foundation plans, views, pieces, roof plans, window door plans, floor plan, ceiling plan, etc.), drawing complete as-built drawings (floor plans, foundation plans, views, cutouts, roof plans, window door plans, floor plans, ceiling plans, etc.), able to calculate $\mathrm{RAB}$, and also able to create $\mathrm{S}$ curves and project time schedules.

\section{Conformity of competency of building engineering vocational school graduates with the needs of the construction industry}

The results of the questionnaire with DU/DI were discussed in a Focus Group Discussion (FGD) with building engineering teachers from SMK Negeri 2 Surabaya, SMK Negeri 3 Surabaya, SMK Negeri 5 Surabaya, and SMK Negeri 7 Surabaya. Based on the FGD, it is found that most of the competencies in the building engineering SMK curriculum are in accordance with the needs in DU/DI, but there were still competencies that are needed by DU/DI that are not yet in included in the vocational high school curriculum.

The competencies included in building engineering can be grouped into 5 main competency groups for building engineering expertise, namely: 
- Architectural work (Drafter)

- Structural work (Engineer)

- Budget plan (Estimator)

- Mechanical and electrical work (ME)

- Construction Management (CM)

The result of the discussion is to fulfill the needs of DU/DI. Therefore, the preparation of the SMK curriculum will further involve the role of DU/DI. Competencies that score low will be reconsidered for their suitability. Competencies that score high will get more attention or hours for students to master.

\section{CONCLUSION}

Based on the results of research and discussion, it can be concluded as follows: (1) Soft skills required by the construction industry are honest, thorough, able to solve problems, adaptable, able to work as a team, and able to work under pressure. (2) Hard skills competencies needed by the construction industry are survey mapping skills, drawing skills (architectural and structural), structural work (planning and implementation), and cost budget planning, and project scheduling.

\section{REFERENCES}

Badan Pusat Statistik (BPS) Indonesia. (2020). Tingkat Pengangguran Terbuka (TPT) Februari 2020.

Bagale, S. (2015). Technical Education and Vocational Training for Sustainable Development. Journal of Training and Development, 1, 15-20.

Chinedu, C. C., Wan-Mohamed, W. A., \& Ajah A.O. (2018). A systematic review on education for sustainable development. In: Journal of Technical Education and Training, 10, 1. Online: https://publisher.uthm.edu.my/ojs/index.php/JTET/article/view/1678 (retrieved 22.20.2019).

Dmitry, Elena M. Prospects for the Development of Further Vocational Education in the Tyumen Region of Russia. Sciencedirect, Procedia - Social and Behavioral Sciences 214 ( 2015 ) 693 - 699

Deseco. (2005). Defining and Selecting Key Competencies. Online: http://www.Oecd.Org/Edu/ Statistics /Deseco.

Estriyanto. Y, Kersten. S, Pardjono, Sofyan. H. (2017). The missing productive vocational high school teacher competency standard in the indonesian education system. Journal of Technical Education and Training (JTET) Vol. 9, No.1.

Francesco Melosi, Campana. G, Cimatti. B. (2018). Competences mapping as a tool to increase sustainability of manufacturing enterprises. Procedia Manufacturing 21, 806-813.

Khan, M., et.al. (2013). Impact of school councils on head teachers' efficiency. Journal of educational research dept of education IUB Pakistan, 16(1), 15-26.

Liu, H., Hartmann, M., Liu, M, \& Hariyanto, D. (2019). Enhancing students' key competencies for Sustainable Development in Chinese Technical and Vocational Education and Training (TVET): implications for TVET teachers. In: TVET@Asia, issue 14, 1-17. Online: http://www.tvetonline.asia/issue/issue-14/liu-etal (retrieved 31.12.2019).

M. Kuijpers dkk. The relationship between learning environment and career competencies of students in vocational education. Journal of Vocational Behavior 78 (2011) 21-30

Pavlova, Margarita. (2009). Technology and vocational education for sustainable development. Queesland: Springer

Peraturan Pemerintah Nomor 29 Tahun 2000 Tentang Penyelenggaraan Jasa Konstruksi

Peraturan Menteri Pekerjaan Umum Nomor 08/PRT/M/2011 tentang Pembagian Subklasifikasi dan Subkualifikasi Usaha Jasa Konstruksi

Ploum, L., Blok, V., Lans, T., \& Omta, O. (2017). Toward a Validated Competence Framework for Sustainable Entrepreneurship. Organization \& Environment, 31(2), 113-132. doi: $10.1177 / 1086026617697039$

Stephen Billett. (2011). Vocational education purposes, traditions and prospects. New York: Springer

Undang-Undang Nomor 2 Tahun 2017 tentang Jasa Konstruksi

Zhang, J. \& Zhang, Y. X. (2012). Study on the Students' competencies for Sustainable Development in Engineering vocational Colleges-taking Shanxi Electrical and Mechanical Vocational and Technical College as an example. In: Journal of Language and literature, 11. 